\title{
CURRENT CLINICAL AND PATHOMORPHOLOGICAL FEATURES OF THE COURSE OF EXPERIMENTAL EXTRAPULMONARY TUBERCULOSIS
}

\author{
Holka G., Vesnin V., Fadeev O., Oliynyk A., Garchusha M., Hanyk T. \\ Kharkiv National Medical University \\ https://doi.org/10.35339/ic.6.3.143-149
}

\begin{abstract}
The purpose of this study was to describe extra-pulmonary tuberculosis modeling and its features in guinea pigs for further use of the results of the experiment in medical and scientific practice. The study involved 40 sexually mature guinea pigs. Modeling of tuberculous spondylitis was carried out on the basis of the method developed by us (Patent No. 112423 (UA) Ukraine). All animals underwent a dynamic follow-up with clinical, X-ray, pathomorphological and laboratory tests. The withdrawal of experimental animals from the experiment was carried out according to the previously developed schedule, in identifying signs of the studied stages of the tuberculous process.

The study gave a possibility to trace the stage of development of tuberculous spondylitis in guinea pig and to trace the current features of the clinical, radiological and pathomorphological course. The identity of the model of the main clinical forms of tuberculous spondylitis in guinea pig and humans was shown.

This study showed that modern intensive specific antibiotic therapy in the conditions of experiment resulted in a delimitation of the destructive process in relatively early stages of development of the disease (4-5 weeks).

The new knowledge about pathomorphological features of the course of tuberculous spondylitis makes it possible to carry out radical surgical interventions on the locomotor apparatus without the risk of generalizing the tuberculous process at an earlier term.

Key words: experimental modeling, extrapulmonary tuberculosis, tuberculous spondylitis,
\end{abstract} treatment.

\section{Introduction}

At present, Ukraine belongs to the group of countries with high levels of tuberculosis cases with a significantly higher incidence than in the vast majority of countries in Central and Eastern Europe $[13,14]$.

The current epidemiological situation is characterized by spread of tuberculosis infection in all its manifestations, which is also accompanied by a gradual increase in the incidence of extrapulmonary tuberculosis (EPT). The difficulties of early detection lead to a relatively late diagnosis of the disease as late as in the period of development of the destructive process, abscesses and fistulas. Diagnostic errors in the early stages of the examination of patients

Corresponding Author:

Grygoriy Golka, MD, PhD, Professor,

Head of the Department of Traumatology and

Orthopedic, Kharkiv National Medical University,

Ukraine. E-mail: gr_golka@ukr.net with EPT play a leading role in development of advanced tuberculosis [3, 12, 16, 17].

It is important to note that at the present time the system of provision of specialized medical care to patients with EPT does not work in our country. The problems of treatment and diagnosis of pulmonary tuberculosis are addressed to the Ministry of Health of Ukraine and specialized medical institutions, while the problems of EPT treatment remain beyond the attention of these institutions $[6,7,13]$.

In the context of the current epidemiological situation in Ukraine, osteoarticular tuberculosis (OAT) is ranked first in the structure of morbidity of extrapulmonary tuberculosis, and in the structure of the total incidence of tuberculosis, the share of extrapulmonary disease accounts for $10.6 \%[7,13]$.

The basic information about the pathogenesis of tuberculosis as a chronic specific infection from the time of Robert Koch to the present day has been obtained through experimental studies, and 
the spine according to the literature, the form and size of vertebrae in guinea pigs differ from human ones, but the general plan of the anatomical structure of the spine is similar [4]. The selection of animals is also due to high susceptibility to MTB.

Modeling of tuberculous spondylitis was conducted on the basis of the original method (Patent No. 112423 (UA) Ukraine) [11]. The utility model was based on the task of creating a model of tuberculous spondylitis maximally close to the natural process according to its clinical and radiological signs.

According to the utility model, the animal is immobilized and in the position on the right or left side, the skin in the region of the lumbar spine projection above the ilium is removed from fur and treated with iodine solution, the surgical field is separated by sterile napkins, and layered external abdominal access to the anterior-lateral surface of the bodies of L2-L4 segments is performed by stratification of the muscles of the anterior abdominal wall and pressing of the parietal layer of the peritoneum along with the contents of the abdominal cavity to the medial side. After removal of the anterior-lateral surface of the vertebral bodies, segmental vessels are visualized, the latter are taken on the holders on both sides, banded and cut, then $0.5 \mathrm{ml}$ of mycobacterium tuberculosis culture of $\mathrm{M}$. bovis suspension of Valle strain is administered under visual control with a syringe into the body of the vertebra. The dressing of segmental vessels significantly degrades circulation in the vertebrae, thereby creating favorable conditions for development of a specific inflammatory process. The postoperative wound is sutured, this is followed by dynamic clinical and radiological control until the appearance of clinical and radiological signs of tuberculous spondylitis.

The study involved 40 guinea pigs. The animals were divided into 4 equal groups.

Groups 1,2, 3 (main) received an injection of $0.5 \mathrm{ml}$ of M. tuberculosis suspension $(0.1 \mathrm{mg}$ of dry weight in $1 \mathrm{ml}$ ) into the vertebral body according to the procedure.

Group 4 was the control one. Animals were injected with a sterile physiological solution $(0.9 \%-0.5 \mathrm{ml})$ into the vertebral body.

Group 1 included 10 guinea pigs receiving specific first-line antibacterial agents (ABA) (isoniazid, streptomycin, rifampicinum).

Group 2 comprised 10 guinea pigs receiving specific second-line antibacterial agents (ABA) (amikacinum, rifabutin, ofloxacin).
Group 3 involved 10 guinea pigs receiving no treatment.

The dose of specific ABAs was calculated based on the animal weight (parenterally) daily.

The choice of the site of infection was determined by a high frequency $>50 \%$ of localization of primary osteitis in the subchondral zone of the vertebral body in patients with TS.

Experimental modeling of EPT was carried out by introducing M.bovis suspension of Valle strain $(0.1 \mathrm{mg}$ dry weight in $1 \mathrm{ml})$ intra-rectally according to the procedure.

In the first stage of the experiment, after the detection of the signs of spondylitis stage of tuberculous spondylitis (in 1 month), 16 animals were removed from the experiment (4 in each group). In the second stage, after the detection of clinical radiological spondylitic stage, 16 animals were removed likewise. The withdrawal from the experiment was carried out by ether overdosing.

Later, we were waiting for the appearance of the post-spondylitic stage or remission of the disease, but the overwhelming number of animals in which EPT was modeled died within 3 to 4 months. The cause of the death of these animals, as confirmed by macroscopic examination on autopsy, was generalization of the infectious process with subsequent damage to the vital organs and systems.

Post-spondylitic stage of the disease was obtained only in 2 guinea pigs of the second group, receiving specific second-line ABAs. Two guinea pigs in the control group were not found to have any signs of the infectious process at the end of the experiment.

All animals underwent follow-up examination with a detailed clinical assessment, weighing, evaluation of the function of the spine and lower extremities. Clinical examination of the animals involved assessment of the behavior, posture and nature of the movements.

All the animals that were taken out of the experiment underwent a pathomorphological study.

\section{Conflict of interests}

The authors declare that they have no competing interests.

\section{Results and discussion}

One month after infection, in all the animals of the main observation group, an increase in general temperature was observed on average by $0.5^{\circ}$, accompanied by an increasing restriction of movements in the large joints of the lower extremities. Loss of body weight of animals ranged from 20.0 to 40.0 grams. Six guinea pigs 
were found to have abscesses on the anterior and medial surfaces of the thighs. Development of abscesses could result from the destruction of the cortical layer near the destruction site and subsequent involvement in the inflammatory process of the perivertebral tissues. X-ray of the spine showed local osteoporosis with focus of damage with a destruction of the subchondral zone.

The next examination of experimental animals showed formation of tuberculous osteitis which later increased in size (only within the vertebra).

Over the next 4-6 weeks, symptoms of intoxication continued to increase (lethargy, appetite loss), weight loss was an average of 60 grams. Some animals were found to have thickening and infiltration of soft tissues in the area of postoperative access, and paravertebrally there was a flexural contracture in the joints of the lower extremities. A marked lameness was detected; the limb of the animal was not loaded, pulling it behind the body (Fig. 1). In some cases, abscesses spread to the thigh area, fistulas were formed. Radiograms registered an increase in destructive centers, occupying the entire vertebra with the transition to an adjacent segment. The foci of destruction contained sequesters of various forms and sizes (Fig. 2).

The withdrawal of experimental animals from the experiment was carried out according to a previously developed schedule. Before euthanasia, the animals were thoroughly examined, and after that, blocks of segments of the lumbar spine affected by the destructive process were produced, the macroscopic specimens were subjected to X-ray and pathomorphologic examination, and pathomorphological studies of the internal organs were performed.

\section{Pathomorphological study}

Anatomical preparation and macroscopic study of spinal specimens were carried out

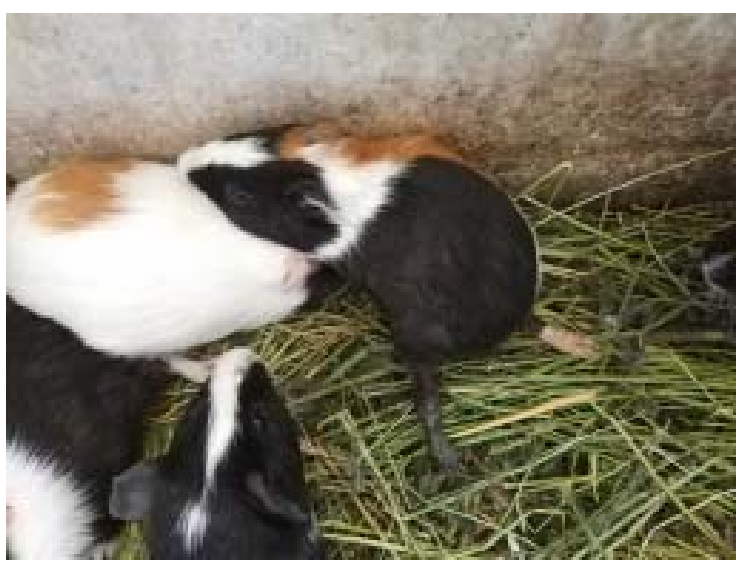

Fig. 1. Appearance of guinea pigs in the spondylitic stage of the disease immediately after withdrawal from the experiment. The study involved macroscopic evaluation of the condition of the spine, musculoligamentous apparatus, detection of congested abscesses, preparation of macroscopic specimens of vertebrae (Fig. 3).

For histological examination, the vertebrae of guinea pigs and adjoining muscles were isolated and fixed in a solution with a mass fraction of neutral formalin $10 \%$. To study the inflammatory process in the vertebrae, decalcification of the bones was performed in a solution with a mass fraction of $4 \%$ nitric acid at the temperature ranging from 18 to $22^{\circ} \mathrm{C}$. The bones after decalcification and muscles adjacent to vertebrae were dehydrated in alcohols of increasing concentration $\left(50^{\circ}, 70^{\circ}\right.$ alcohols and twice at $\left.96^{\circ}\right)$ and in alcohol with ether (1:1 solution), and enclosed in celloidine. Histologic slices were made using Reichthert sledge microtome and stained with hematoxylin and eosin and by Van Gieson. Histological analysis was performed using Axio Star Plus (Carl Zeiss) light microscope, taking photos with Canon Power Shot A610 digital camera and AxioVision computer software.

Histological examination in 1 month after the inflammatory process modeling clearly showed the signs of inflammation (infectious process) in all animals.

Histological specimens made from the lumbar spine of the guinea pigs infected with mycobacterium tuberculosis and treated with specific first-line ABAs in the spongy tissue of the vertebral body, showed foci of specific inflammatory process, manifested by formation of epithelioid (center - epithelioid cells) and necrotic (center - caseous necrosis) tubercles. Around the centers of the tubercles there was a shaft of epithelioid cells followed by lymphocytes, macrophages, plasma cells, and polynuclear giant Pirogov-Langhans cells (Fig. 4).

After the treatment of animals with specific second-line ABA, microscopic analysis revealed the changes typical for cessation of the inflammatory process. There was sclerosis of trabeculae and cortex, forming on the border with the area of impairment of newly formed spongy bone tissue with a significant density of brightly colored osteocytes on the surface. The cells did not form lacunae and contained large hyperchromic nuclei and basophilic cytoplasm. Intertrabecular spaces contained reticulofibrous tissue.

However, restoration of the integrity of the vertebral body was not observed. Connective 

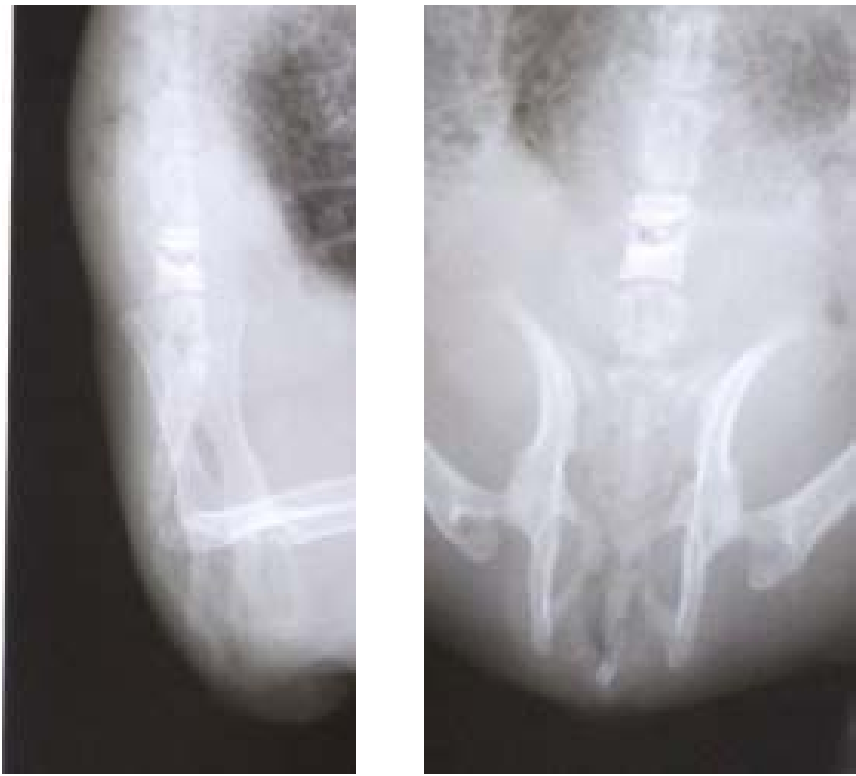

Fig. 2. X-ray of the spine. Contact destruction of the vertebrae

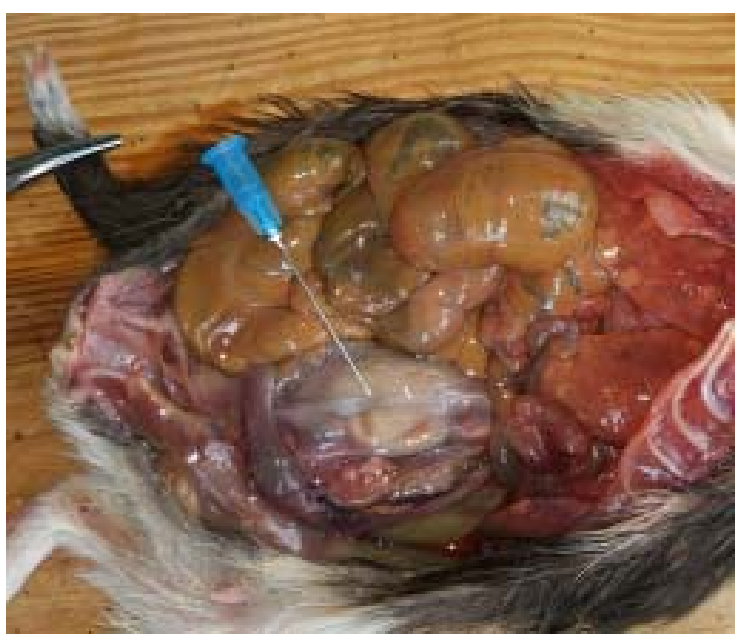

Fig. 3. Visualization of bilaterally congested abscesses of the spine of the guinea pig of the first group

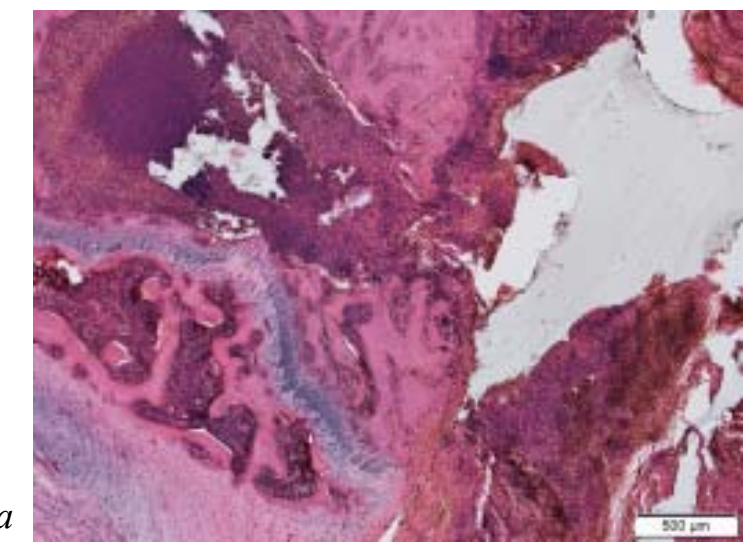

tissue of varying degrees of maturity with a significant number of vessels of different diameters, densely packed fibroblasts, the presence of lymphoid and plasma cells, formed in the area of impairment by its tuberculous inflammation after the action of specific secondline ABA.

The pathological changes found 1 month after EPT modeling in the affected vertebrae of guinea pigs that did not receive specific ABA, were characterized by the following pattern: evaluation of the specimen at the level of destruction showed that infiltrate was located subchondrally. Among infiltrates there was a small necrotic focus with the presence of elements of decay.

Among inflammatory infiltrates there were necrotic foci with granular disintegration of cellular elements of granulation tissue. Along with

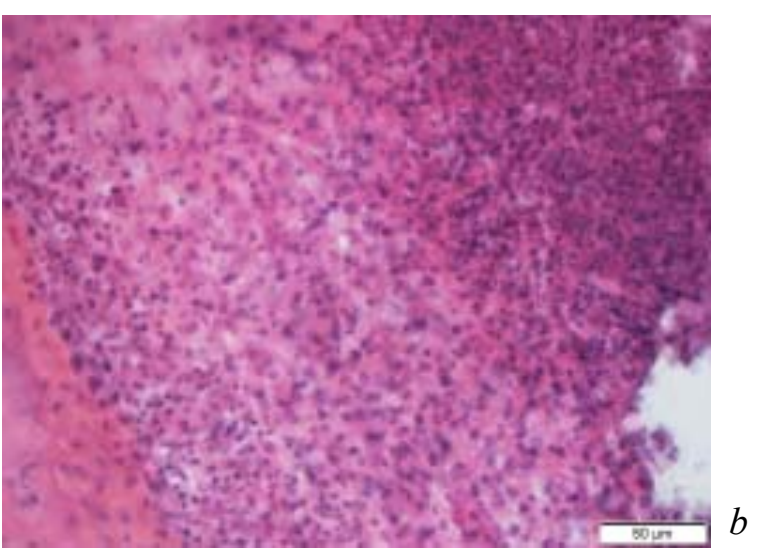

Fig. 4. A fragment of the vertebral body of the lumbar spine of a guinea pig after modeling of tuberculosis and treatment with specific first-line ABA: a) focus of a specific inflammatory process, destruction of the cortical layer; b) peripheral part of necrosis tubercle, macrophages, lymphocytes, plasmocytes. H\&E stain 
infiltrates there was an inflammatory edema of loose connective tissue. In the subchondral bone at the border with the subchondral tuberculosis described above there were necrotic changes in the bone trabeculae.

In the tubercle there was a high density of epithelioid cells with a characteristic structure, namely a small weakly basophilic core, surrounded by abundant cytoplasm.

In the intertrabucular space, destruction of the bone marrow and formation of productive inflammation foci and epithelioid-cell tubercles, which differ from each other, was observed. Some of them did not contain all the elements of the tubercle. They were represented by epithelioid cells with light oval nuclei. In the marginal parts of the tubercles there was a high density of lymphocytes, macrophages and fibroblasts. Plasma cells were singular.

Thus, morphological study showed the presence of an active tuberculous process in the bodies of vertebrae and paravertebral tissues in animals with modeled tuberculosis and treatment with specific first-line ABAs, as well as in animals without specific treatment.

It is important to note that the degree of severity of destructive changes in the affected vertebrae in untreated animals and those receiving first-line ADAs was practically the same.

Animals with modeled tuberculosis treated with specific second-line ABAs were found to have inhibition of the pathological process with the formation of young bone and connective tissue of varying degrees of maturity, and the presence of an area separating the inflammatory focus from healthy tissue in the early stages of the disease (one month).
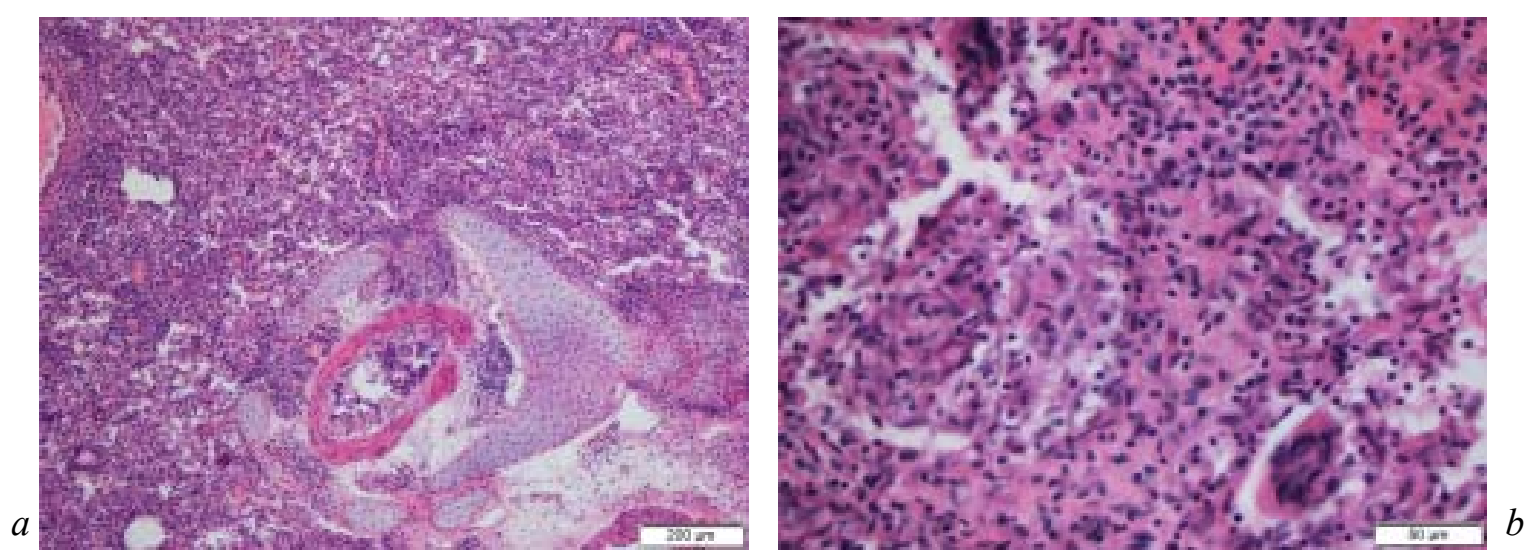

Fig. 5. A fragment of a guinea pig lung after modeling of tuberculosis and treatment with first-line ABAs: a) absence of an alveolar structure, a productive specific inflammation;

b) productive epithelial tubercle with a giant Pirogov-Langhans cell. H\&E stain

Microscopic examination of the internal organs of animals with modeled EPT and treatment with specific first-line ABAs and untreated animals showed pathological changes characteristic of generalization of the tuberculous pathological process.

Pathomorphological study showed structural impairment of the lungs: alveolar structure was not traced; desquamation of the epithelium in bronchioles and bronchi, their lumen was filled with fluid, peri-bronchial foci of lymphocytes and plasmocytes. There was productive specific inflammation. In all fields of view, there were multiple tubercles of epithelioid-cellular structure (Fig. 5 a). There were several layers of epithelial cells, macrophages, lymphocytes and plasma cells. There were polynuclear Pirogov-Langhans cells among epithelioid cells (Fig. 5, b).

In contrast to the animals with modeled tuberculosis treated with first-line agents and the untreated ones, the alveoli in the lungs of the control group and of animals receiving secondline ABAs, were in a state of dystelectasis, partially expanded, filled with insignificant amounts of fluid. Interalveolar partititions were thin. Alveolocytes were located in one row on the basement membrane, had an eosinophilic cytoplasm and a round small hyperchromic nucleus. Bronchioles had a folded inner membrane with a cylindrical single-row epithelium, the nuclei were located on the basement membrane.

Microscopic examination of the liver in animals of experimental groups showed structural impairment: capillary sinuses were not defined, diffused inflammatory infiltrates around isolated preserved liver triads, hepatocytes were located in separate islets without the formation of a trabecular structure. Thus, multiple productive b

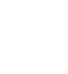


necrotic tubercles found around the central veins were found to have necrotized, or epithelioidcellular center. Around it there was a shaft of epithelial cells, macrophages, lymphocytes, and plasma cells (Fig. 6). The revealed morphological picture is characteristic of tuberculous inflammation.

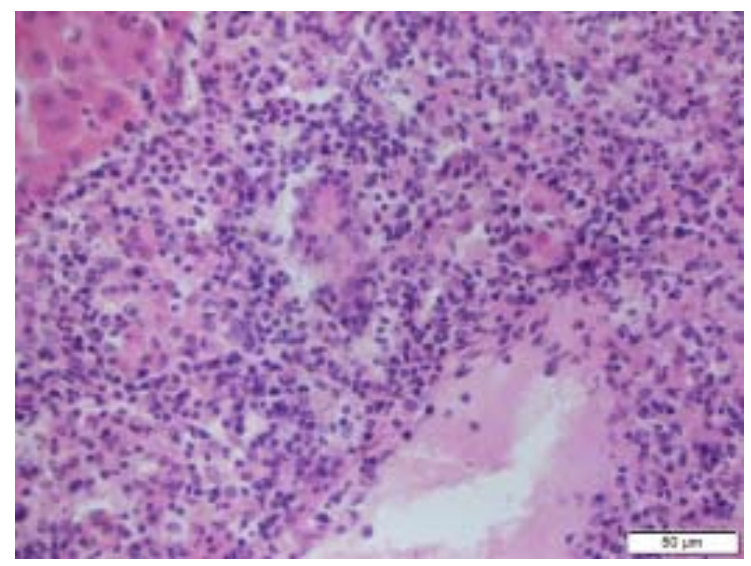

Fig. 6. Fragment of a guinea pig liver with modeled tuberculosis following administration of first-line ABAs (Group 1): epithelioid, lymphoid cells, macrophages, dystrophically altered hepatocytes. H\&E stain

On histological specimens of the liver of control animals and animals receiving specific second-line ABAs, the connective tissue capsule and hepatic lobes were clearly differentiated. Central veins were located in the center of the lobes, hepatocytes radially departed from it, forming a trabecular structure. Cytoplasmic membrane of cells was clearly visualized, small eosinophilic inclusions were noted in the cytoplasm. The described structure is characteristic of the norm, which indicates the high efficiency of specific therapy with secondline ABAs, and the absence of generalization of the tuberculous process secondary to treatment with these agents.

Summing up the observations of guinea pigs, we conclude that in all cases (30 guinea pigs), under this method of infection, tuberculous spondylitis was confirmed clinically and pathohistologically.

In our experiment it was possible to trace the stage of development of tuberculous spondylitis in guinea pig and to correlate the phases of its evolution with the stages of development of TS, set forth in the generally accepted classification of E. M. Belendir [2] in accordance with the tasks set.

The identity of the tuberculosis model of the spinal cord in guinea pig with intravertebral infection was revealed in the human with the main clinical forms of TC: tuberculous osteitis developed up to 4 weeks (1 stage according to the classification of E.M. Belendir), up to 8-9 weeks - there was progression of osteitis with the onset of spondylitis (2 stage in this classification) with subsequent distribution of destruction on adjacent segments of the spine $[1,3]$.

It should be noted that fundamental research regarding the features of the current course of extrapulmonary tuberculosis and its pathomorphologic features is not performed in our country. Recent Russian-language publications on experimental modeling of this disease date back to the 1960 s. There are practically no publications on EPT modeling in the last 30 years in foreign literature.

Crucially important, in our view, is the lack of experimental studies in the world scientific literature on the study of the impact of not only modern antibacterial anti-tuberculosis agents (amicacinum, rifabutinum, ofloxacin), but also agents which have been introduced as part of standard treatment over the last decade, on the destructive specific tuberculous inflammatory process of the spine. The only exception is the study of the effect of streptomycin on the course of tuberculous inflammation of the musculoskeletal system, conducted by O.P. Skoblin in 1953 [14].

Scientific works of the leading experts of Leningrad Institute of Tuberculosis Surgery state that pathogenesis of tuberculosis is the most important violation of microcirculation around the lesion, which plays a major role in the spread of infection, its localization in organs and tissues, in the very development and course of tuberculosis inflammation, the role of tuberculosis inflammation, and the role of tuberculosis inflammation, primary focal lesions of organs $[2$, $5,8]$. The procedure of ligature of segmental vessels in guinea pigs, which allowed us to create an experimental model of pulmonary tuberculosis in all experimental animals, was aimed at the violation of microcirculation in the zone of infection during the experiment.

\section{Conclusions}

Based on the histological examination of vertebrate bodies, the animals treated with specific first-line ABAs were found to have evident morphological features of tuberculous inflammation. The animals treated with specific second-line ABAs were shown to have inhibition of the pathological process with the formation of young bone and connective tissue of varying 
degrees of maturity but without restoring the integrity of the vertebral body.

Microscopic study of the internal organs of the guinea pigs showed a specific productive inflammation in animals with modeled tuberculosis in which generalization of tuberculosis occurred in the lungs and the liver, morphological features of which were the same in both groups.

The foregoing indicates the low effectiveness of the antibacterial action of specific first-line ABAs, and the high efficiency of the second-line ABAs, the absence of generalization of the tuberculous process secondary to treatment with these agents.

Thus, this study showed that modern intensive specific antibiotic therapy in the conditions of experiment allows to achieve a delimitation of destructive process in relatively early stages of development of the disease (45 weeks).

The new knowledge about the pathomorphological features of the EPT course secondary to specific antibiotic therapy allows for radical surgical intervention on the locomotor apparatus without the risk of generalization of the tuberculosis process at an earlier term.

In our opinion, the prospects for further research in experimental EPT are as follows: testing of diagnostic tests, testing of medicinal products, development of surgical methods of treatment, testing of the use of various pathogenic methods of treatment.

\section{References}

1. Belendir E.N. Eksperimentalnaya patologiya i hirurgiya vnelegochnogo tuberkuleza i ee klinicheskoe znachenie // Hirurgiya vnelegochnogo tuberkuleza. - L., 1983. - P. 13-27.

2. Belendir E.N. Sovremennoe predstavlenie o patogeneze vnelegochnogo tuberkuleza // Aktualnyie voprosyi diagnostiki i lecheniya tuberkuleza: nauchnyie trudyi Vseros. nauch.-prakt.konf.- SPb., 2006. P. 225-226.

3. Bellendir, E. N. (2006). Sovremennoe predstavlenie o patogeneze vnelegochnogo tuberkuleza. Aktualnyie voprosyi diagnostiki i lecheniya tuberkuleza, Nauchnyie trudyi Vserossiyskoy nauchnoprakticheskoy konferentsii. Sankt-Peterburg, 225-226.

4. Berghov, P. K. (2010). Melkie domashnie zhivotnyie. Moskva: Akvarium-print.

5. Vnelegochnoy tuberkulez. (2000). Rukovodstvo dlya vrachey / Pod red. Vasileva, A. V. SanktPeterburg.

6. Golka, G. G., Vesnin, V. V., Burlaka, V. V., Oliynik, A. O., Garkusha, M. A. (2017). Zagalni printsipi diagnostiki tuberkuloznogo spondilitu. Travma, 18(3), 95-101.

7. Golka, G. G., Fadeev, O. G., Istomin, D. A., VesnIn, V. V. (2015). Kistkovo-sugloboviy tuberkuloz yak skladova chastina problemi hvorobi. Tuberkuloz, Legenevi hvorobi, VIL-InfektsIya. 21, 111-115.

8. Kornev, P. G. (1971). Hirurgiya kostno-sustavnogo tuberkuleza: v 3 t. Leningrad: Meditsina.

9. Kostno-sustavnoy tuberkulez / pod. red. Yu.N. Levasheva i A.E. Garbuza. - M.: Meditsina i zhizn, 2003. - 294 p.

10. Levashev, Yu. N., Garbuz, A. E. (2003). Kostno-sustavnoy tuberkulez. Ot P. G. Korneva do nashih dney. Moskva, 201-240.

11. Patent 112423 (UA) Ukraina, MPK: G09B 23/28, G09B 25/00. Sposib modelyuvannya tuberkuloznogo spondilitu // Vesnin V.V., Golka G.G.; zayavnik I patentovlasnik Harkivskiy medichniy natsionalniy universitet. - \# u 2016 07946: zayavl.18.07.2016; opubl. 12.12.2016, Byul. \# 23.

12. Perelman, M. I. (2011). Zaglyanem vpered. Problemyi tuberkuleza, 8, 3-4.

13. Porivnyaini dani pro rozpovsyudzhenIst tuberkulozu ta efektivnist diyalnosti protituberkuloznih zakladiv Ukraini za 2007-2017rr. (2018). AMN Ukrayini ta In. Kyiv.

14. Feschenko, Yu. I., Melnik, V. M. (2009). OrganizatsIya likuvannya hvorih na tuberkuloz. Kiyiv: Zdorov'ya.

15. Chistovich A.N. Patologicheskaya anatomiya i patogenez tuberkuleza. - L., 1973.

16. Diehn, F. E. (2012). Imaging of spine infection. Radiol Clin North Am, 50(4), 777-798.

17.Ganavalli, S. A., Shetty, P. C., Kulkarni, R. D., Biradar, U. (2013). Per as a diagnostic tool for extra-pulmonary tuberculosis. J. of Clinical and Diagnostic Research, 7(6), 1012-1015. 